\title{
Experimental evidence of subsurface feeding by the burrowing ophiuroid Amphipholis gracillima (Echinodermata)
}

\author{
M. L. Gielazyn ${ }^{1, *}$, S. E. Stancyk ${ }^{1,2}$, W. W. Piegorsch ${ }^{3}$ \\ ${ }^{1}$ Marine Science Program, ${ }^{2}$ Department of Biological Sciences, ${ }^{3}$ Department of Statistics, \\ University of South Carolina, Columbia, South Carolina 29208, USA
}

\begin{abstract}
Knowledge of the feeding habits of infaunal deposit-feeders is essential to understand their role in the movement of sediment-bound material and nutrients and in trophic transfer. Depositfeeding ophiuroids are abundant in the world's oceans but many details of their intricate feeding behaviors are unknown. We used fluorescent polystyrene microspheres in a subsurface food layer to demonstrate that Amphipholis gracillima, an infaunal ophiuroid known to feed on surface particles, is also capable of consuming subsurface particles in the laboratory. Although physical conditions varied only slightly during experiments there was a significant effect of temperature on the number of microspheres consumed. Additional experiments using layers of microspheres with and without food demonstrated that food layers significantly influenced the disc depth of A. gracillima, whereas layers without food did not. Utilizing subsurface sources of food might give burrowing organisms access to more sources of nutrients, decrease sublethal predation and lead to more stable populations over time.
\end{abstract}

KEY WORDS: Ophiuroid - Brittlestar - Subsurface deposit-feeding $\cdot$ Microsphere $\cdot$ Generalized linear model

\section{INTRODUCTION}

Marine deposit-feeding infauna and epifauna such as ophiuroids, polychaetes, bivalves and holothurians are integral parts of soft bottom marine communities (Rhoads 1974, Cadée 1979, Fauchald \& Jumars 1979, Levinton 1989). These deposit-feeders ingest particles and/or clumps of sediment, consuming associated meiofauna, microfauna, plant material, bacteria, and detritus (Hunt 1925, Rhoads 1974, Powell 1977. Fauchald \& Jumars 1979, Lopez \& Levinton 1987. Decho 1990). Through their feeding behavior, depositfeeders influence the cycling of nutrients and chemical compounds (Rhoads 1974), as well as the physical characteristics of the sediment (Lopez \& Levinton 1987, Levinton 1989). Subsurface deposit-feeders, in particular, have the potential to play an important role in the global carbon cycle by increasing the rates of biomineralization and/or decreasing the amount of carbon

\footnotetext{
•E-mail: gielazyn@sc.edu
}

that is permanently buried. They also have the potential to influence the location and availability of pollutants (Olsen et al. 1982).

Infaunal deposit-feeding ophiuroids, although not as thoroughly studied as other groups, are abundant in all oceans of the world and frequently dominate soft bottom macrobenthic communities (Thorson 1957, Barnard \& Ziesenhenne 1961, Buchanan 1964, Bowmer \& Keegan 1983, Duineveld \& Van Noort 1986). Ophiuroids are frequently subjected to lethal or sublethal predation by a variety of fishes, shrimps, and crabs in many parts of the world (Blegvad 1914, Hunt 1925, Duineveld \& Van Noort 1986, Feder \& Pearson 1988, Theiling 1988, Pape-Lindstrom et al. 1997). They are well known for their ability to rapidly regenerate tissues lost to sublethal predation (Singletary 1970, Bowmer \& Keegan 1983, Stancyk et al. 1994), and Pape-Lindstrom et al. (1997) have demonstrated that consumption of infaunal brittlestar arms is a significant trophic pathway in some soft-sediment habitats. Warner (1982, Table 1) has summarized past ophiuroid feeding research, but much is still unknown about the 
more intricate aspects of their feeding habits and behaviors. Knowledge of ophiuroid feeding behaviors is essential before we can assess the role these organisms play in trophic transfer of nutrients and possibly pollutants both within benthic communities and between benthic and pelagic communities.

Amphipholis gracillima (Stimpson) (= Microphiopholis gracillima; see Hendler et al. 1995, p. 152) is an amphiurid brittlestar commonly found throughout the southeastern United States (Thomas 1962, Ruppert \& Fox 1988, Hendler et al. 1995). It burrows approximately $10 \mathrm{~cm}$ into the sediment and occurs in densities up to $56 \mathrm{~m}^{-2}$ (Singletary 1980). Adults of this species have a disc diameter of 4.6 to $8 \mathrm{~mm}$ with thin arms 100 to $150 \mathrm{~mm}$ long (Hendler et al. 1995) which extend to the surface through 2 to 3 mucus-lined burrows. The digestive system of $A$. gracillima, which is contained within the disc, is composed only of a mouth and a saclike stomach (Hyman 1955). A. gracillima has been described as both a selective and non-selective surface deposit-feeder, and has also been known to employ suspension feeding to obtain food (Singletary 1980, Clements \& Stancyk 1984, Hendler et al. 1995). In general, however, A. gracillima collects particles and moves them to its mouth with its tube feet like other amphiurid brittlestars, as previously described by Woodley (1975). A. gracillima has also been thought to be a subsurface deposit-feeder (Singletary 1980), although this has not been demonstrated conclusively. Feeding on subsurface particles might reduce the risk of predation or satisfy a portion of the nutritional requirements of $A$. gracillima.

Direct observation of subsurface feeding behavior is difficult if not impossible. Consequently, many previous studies of other deposit-feeding organisms have used indirect evidence such as the orientation of the organism's body (anterior end located within the sediment, posterior end at the sediment surface; e.g. Mangum 1964) or the color of its fecal pellets (Cadée 1979) to conclude ingestion of subsurface particles. Studies of burrowing brittlestars have suggested that the organisms consume subsurface particles, but provided no real evidence supporting or refuting the hypothesis (e.g. Pentreath 1970).

The primary purpose of this study was to determine unequivocally whether Amphipholis gracillima ingests subsurface particles in the laboratory. In our experiments, fluorescent microspheres were used to ensure that the origin of particles found in the gut of $A$. gracillima was known. The second objective was to quantify the rate of subsurface ingestion. The third objective was to determine whether A. gracillima would move towards subsurface concentrations of food by ascertaining the location of the buried brittlestars' discs relative to a subsurface food layer.

\section{MATERIALS AND METHODS}

Amphipholis gracillima and sediments were collected from a site in Debidue Creek in the North InletWinyah Bay National Estuarine Research Reserve, Georgetown County, South Carolina, USA $\left(33^{\circ} 20^{\prime}\right.$ $\left.22.62^{\prime \prime} \mathrm{N}, 79^{\circ} 10^{\prime} 00.42^{\prime \prime} \mathrm{W}\right)$. Acclimation and experiments were conducted from May to June 1997 in flowthrough fiberglass seawater tanks at the Belle $W$ Baruch Marine Field. Laboratory. All seawater was filtered through 20 and $5 \mu \mathrm{m}$ filters to remove potential food particles, then aerated. Seciment was sieved through a $3 \mathrm{~mm}$ mesh to homogenize it and remove large shells and macrofauna. Experiments were conducted in complete darkness for 12 h overnight, when A. gracillima has been observed to be particularly active (J. McAlister pers. comm.).

Brittlestars were collected from subtidal sediment $5 \mathrm{~d}$ before the beginning of each experiment. Individuals were placed into $750 \mathrm{ml}$ NASCO Whirl-Paks ${ }^{\circledR}$, and transported to the laboratory in a cooler of seawater. Once at the lab, brittlestars were rinsed clean of residual sediment then anaesthetized with magnesium chloride ( $3.5 \%$ solution mixed 1:1 with seawater), so they could be handled and examined without damage. Only adult-sized individuals with fully grown discs and 4 or 5 complete arms were used for experiments. A fully-grown disc was defined as one that completely covered the most proximal arm segments, which have no aboral arm plates. Sex was determined by the gonad color for each individual (Singletary 1980). Anaesthetized individuals chosen for the experiments were placed in open-topped $50 \mathrm{mI}$ plastic Falcon ${ }^{(2)}$ centrifuge tubes with the cone-shaped bottom removed, which were filled with sieved natural sediment. The bottom of the Falcon centrifuge tubes were covered with $1 \mathrm{~mm}$ mesh window screen for the duration of the experiments; the top was only covered for the first $24 \mathrm{~h}$ to encourage burrowing. Brittlestars were acclimated in the Falcon ${ }^{(B)}$ centrifuge tubes with no additional food sources for the $5 \mathrm{~d}$ between collection and the beginning of the experiment. Brittlestars that would not burrow or which left the tubes during the acclimation period were not used in experiments.

Food preparation. Tetramin ${ }^{\otimes}$ Tropical Fish Food was used for food in all experiments, because Amphipholis gracillima has been maintained healthily on Tetramin ${ }^{(x)}$ in the laboratory for long periods of time (S.E.S. unpubl.). Tetramin ${ }^{*}$ is arguably a much richer food source (45\% protein, $5 \%$ fat) than brittlestars encounter naturally. Small (48 $\mu \mathrm{m}$ average diameter, $1.05 \mathrm{~g} \mathrm{ml}^{-1}$ specific gravity), green, fluorescent polystyrene divinylbenzene microspheres (Fluorescent Polymer Microspheres [Dry], catalog number 35-8, Duke Scientific Corporation, Palo Alto, CA) were used to track the 
food source. Polystyrene microspheres have been successfully utilized in invertebrate feeding experiments (e.g. Self \& Jumars 1988, Ward \& Targett 1989, Grossmann \& Reichardt 1991). Although artificial particles are not a perfect substitute for natural particles, these particular microspheres were chosen because Clements \& Stancyk (1984) found that $A$. gracillima preferentially ingests particles 30 to $60 \mu \mathrm{m}$ in diameter. They were also chosen because they fluoresce brightly when illuminated with longwave ultraviolet (UV) light and in the absence of other light individual particles can be seen with the naked eye. Finally, deposit-feeding invertebrates preferentially ingest particles of low specific gravity (Self \& Jumars 1988).

To prepare food for the experiments, $0.25 \mathrm{~g}$ of Tetramin ${ }^{*}$ and $0.035 \mathrm{~g}$ of microspheres were well mixed with $15 \mathrm{ml}$ of sieved moist natural sediment, and flattened into a uniform disk approximately $2 \mathrm{~mm}$ thick and $8.5 \mathrm{~cm}$ in diameter. The disks were checked for a uniform distribution of microspheres with a UV light; a $1 \mathrm{~mm}$ mesh fiberglass window screen was pressed on top of the disk; the entire mixture was wrapped in plastic wrap and frozen for at least $24 \mathrm{~h}$.

Subsurface feeding experiments. Four separate experiments utilizing $11,6,5$, and 8 individuals, respectively, were run in May and June 1997. Brittlestars that would not burrow or that left their containers during the acclimation or experiments were removed from the

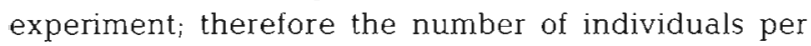
experiment varied. During the acclimation periods and experiments, environmental variables (temperature, salinity, and dissolved oxygen of the seawater) were automatically recorded hourly with a Hydrolab Data Sonde 3. For each brittlestar a $950 \mathrm{ml}$ plastic container (height $=14.5 \mathrm{~cm}$ ) was filled with fresh, sieved natural sediment to $6.5 \mathrm{~cm}$ below the top of the container. The prepared frozen food mixture was lowered onto the sediment surface with forceps, taking care not to deposit microspheres on the sides of the container. The layer defrosted rapidly, allowing the screen to be removed. Next, 3 samples of the food layer were taken at random locations to calculate initial microsphere densities. Samples were collected by pushing a drinking straw through the layer, applying suction and removing the sediment in the straw. Each sample covered an area of $0.28 \mathrm{~cm}^{2}$ and was 1 to $2 \mathrm{~cm}$ deep. The container was carefully filled to the top with sediment without disturbing the food layer.

To insert a brittlestar into the container, the barrel of a $50 \mathrm{ml}$ plastic syringe $(2.9 \mathrm{~cm}$ diameter $)$ with the needle end removed was pushed into the center of the container and the sediment within the syringe core was scooped out without disturbing the remainder of the food layer. A brittlestar was immediately inserted into the prepared hole by removing the bottom screen

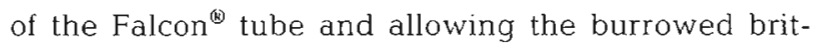
tlestar and sediment to gently slide out of the tube and into the syringe; the syringe was then removed. The brittlestar and sediment were inserted into the container through the layer of food so that the sediment from the Falcon ${ }^{\otimes}$ tube was flush with the sediment surface of the container. Each container was checked with UV light and any microspheres visible on the surface were removed with a pipette. The containers were placed in a flow-through tank and the seawater was maintained 5 to $10 \mathrm{~cm}$ above the top of the containers. For the duration of the experiments, all containers were monitored for fluorescent microspheres on the sediment surface by shining a hand-held UV light on the sediment surface. The experiments were not left unattended for more than 5 consecutive minutes. When microspheres were seen at the surface they were immediately removed with a Pasteur pipette to insure that no microspheres were available for ingestion at the sediment surface. Upon termination of the experiment each brittlestar was carefully removed from the sediment, gently rinsed until free of microspheres, and placed in a clean dish of seawater. The brittlestar was promptly induced to autotomize its disc by holding the disc with a pair of forceps. The autotomized disc and gut contents were placed in a numbered container and held for examination. At a later date all individual discs were emptied of their contents by placing them in seawater and gently pumping the disc with forceps. Additional material was removed from the gut with a gentle stream of water from a pipette. Stomach contents were recorded and the number of microspheres in the brittlestar guts was counted.

Disc depth experiments. Three separate disc depth experiments utilizing 14,13 , and 14 individuals were conducted in June 1997. The number of individuals per experiment varied because those who left their containers or would not burrow were not used. Collection and experimental procedures were similar to the subsurface feeding experiments except that food or control layers were placed $3.5,6.5$, or $9.5 \mathrm{~cm}$ below the sediment surface. The layer for the food treatment was prepared in an identical fashion to the food layers used in the subsurface experiments. The layer for the control treatment was prepared in the same manner but without any Tetramin ${ }^{\circledR}$ added. Microspheres brought to the surface during the experiment by burrowing activity were not removed. After $12 \mathrm{~h}$, the sediment containing the brittlestars was carefully removed from the containers. The sediment was then gently broken apart and the distance of the brittlestar's disc from the treatment layer and the sediment surface was measured. Measurements were corrected for the amount the sediments lengthened when they were removed from the containers. 
Data analysis. Statistical analyses for subsurface feeding and disc depth experiments were conducted at a significance level of 0.05 (unless otherwise noted) using SAS Statistical Software (SAS Institute Inc. 1989 1990, 1993). Pearson correlation coefficients (Moore \& McCabe 1993) were calculated for all pairwise combinations of water temperature, salinity, and dissolved oxygen to determine if any multicollinear relationships existed among these possible predictor variables in the subsurface feeding experiments

Initial microsphere densities for the subsurface feeding experiments were estimated by counting subsamples of the food layers. Variance heterogeneity in the density data was observed across experiments, hence the normal-based linear model was considered inappropriate for data analysis. However, the observed coefficients of variance for the data were roughly constant, leading to the consideration of a gamma distribution for the data (Piegorsch \& Bailer 1997). Accordingly, a gamma generalized linear model (GLiM) was employed. A 1-way analysis of deviance, which is a modified analysis of variance for GLiMs, was used to determine if the microsphere densities were statistically similar between containers within experiments (Piegorsch \& Bailer 1997).

The statistical analysis of the number of microspheres contained in the gut contents of each brittlestar was conducted using a GLiM with a Poisson distribution for the data. The specific link function for the GLiM was taken to be the log link (Piegorsch \& Bailer 1997). The corresponding log-linear model included as regression variables the initial number of microspheres per square centimeter in the food layer (as a quantitative covariate), sex of the brittlestar, and the average temperature, salinity, and dissolved oxygen of the water during each experiment. (Note that each unique combination of temperature, salinity, and dissolved oxygen corresponds to a unique experiment, hence any potential differences among experiments are confounded with possible differences among these combinations of regression variables.) Significance of these regression variables was assessed via an analysis of deviance. Data variability in excess of that predicted under the Poisson model was corrected by including an additional overdispersion parameter in the log-linear model.

For the disc depth experiments, 2 outcome variables were considered: the distance from the brittlestars discs to the treatment layer and the distance from the brittlestars' discs to the sediment surface. For both variables, we assumed that a normal linear model was valid then assessed whether the results could be pooled over different experiments using an analysis of variance (ANOVA) model that contained terms for each of the following factors: treatment (control vs food), depth of layer $(3.5,6.5$, or $9.5 \mathrm{~cm})$, experiment, and all possible 2-and 3-way interactions among these factors. To assess the effect of the experiment factor, all possible singleton and interaction terms in the ANOVA that contained the experiment factor were tested. If all were found to be insignificant, then the experiment factor was deemed not to have an effect and so the data could be pooled over experiments. If this was indeed the case, then the reduced ANOVA was fit containing only terms for treatment, depth, and a treatment $x$ depth interaction. If the interaction was found to be significant, then further pooling across depths to test the treatment term would be inappropriate (Neter et al. 1990). In this case, any analysis of the treatment effect or of the depth effect was conducted by stratifying on the other variable. To assess the model fit, residuals were studied for departure from standard ANOVA assumptions, including a Shapiro-Wilk test for departure from normality (Shapiro \& Wilk 1965).

Under this ANOVA, interest in the disc depth experiments with both outcome variables centered on (1) whether pooling over experiment was valid, and if so (2) whether treatment $x$ depth interaction was significant. If the interaction was significant, then comparisons were made (3) between food and control groups at each level of depth using the distance from the brittlestar disc to the layer as an outcome variable, and (4) among depth levels separately in the control and food groups using the distance from the brittlestar disc to the sediment surface as an outcome variable.

\section{RESULTS}

\section{Subsurface feeding experiments}

This research shows that Amphipholis gracillima will ingest subsurface particles in the laboratory. Over the 4 experiments, only 2 individuals were found with completely empty guts, probably because they egested the contents when disturbed, which is not uncommon in ophiuroids (Hunt 1925, Skjaeveland 1973, Feder 1981). Because they may or may not have ingested microspheres prior to egestion, these individuals were not included in the data analysis. Twenty-eight of the 29 remaining brittlestars ingested subsurface microspheres; the one with no microspheres had other particles in its gut. The number of microspheres recovered from the brittlestar guts was extremely variable, ranging from 0 to 1160 (Fig. 1). The maximum number of microspheres ingested in Expts 1,2, and 3 was between 395 and 570; in Expt 4 the maximum was 1160 in 1 individual, but no others ingested over 620 . Sediment particles of various sizes were found in all of the brittlestar guts, and many of the guts also contained thick globules which were probably comprised of partially 


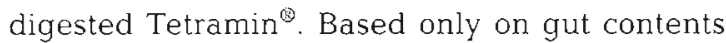
at the end of the experiments, brittlestars ingested from 0 to 97 microspheres $\mathrm{h}^{-1}$; this rate does not include ingestion of other particles and sediment grains.

The estimated initial microsphere densities of the food layers in the experimental containers were quite variable within experiments, despite careful weighing and mixing. Over the 4 experiments they ranged from 4171 to $11966 \mathrm{~cm}^{-2}$ (Fig. 2). The analysis of deviance (which was conducted at an alpha of 0.10 to ensure that any initial differences in microsphere densities were not overlooked) demonstrated that microsphere densities were significantly different between individual containers within Expts 1, 2, and 3, but they were not different within Expt 4 (Table 1). Therefore, all statistical analyses with the subsurface feeding data were adjusted for possible differences in microsphere densities by including initial density as a quantitative covariate.

The correlation analysis of environmental data showed a marginal negative correlation ( $\mathrm{r}=$ -0.417 ) between water temperature and dissolved oxygen, a strong negative correlation between dissolved oxygen and salinity $(r=-0.871)$, and a strong positive correlation between water temperature and salinity $(r=0.746)$. Water temperature, salinity, and dissolved oxygen during the 4 experiments were fairly consistent over time, although subtle differences between experiments were noted (Table 2).

Results of statistical analysis of factors possibly influencing the number of microspheres ingested over the 4 experiments are shown in an analysis of deviance table (Table 3). Water temperature was the only factor to have a significant effect on the number of microspheres found in brittlestars' guts $(p=0.003)$

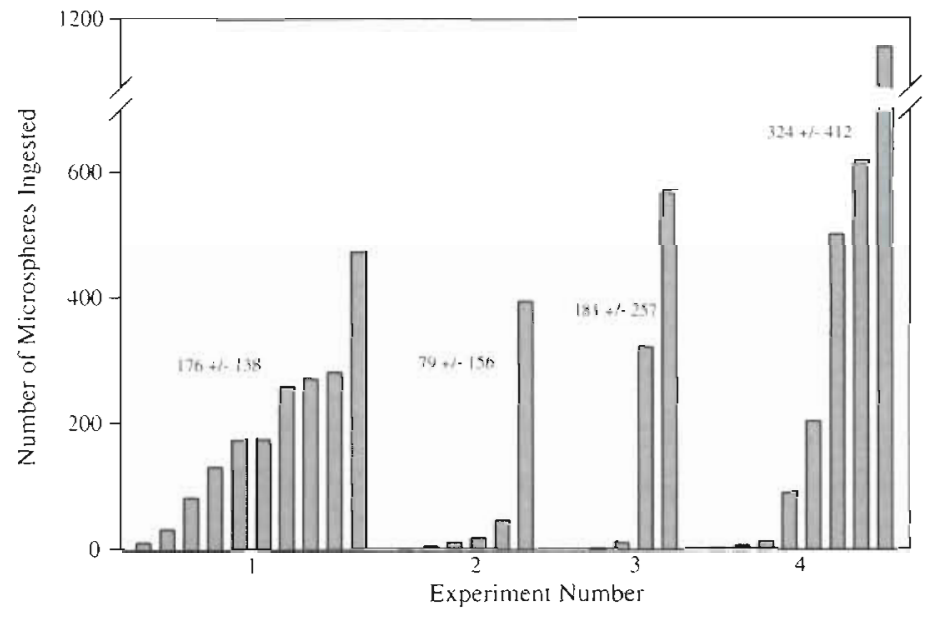

Fig. 1. Amphipholis gracillima. Number of microspheres ingested over a $12 \mathrm{~h}$ period in subsurface feeding experiments. Each bar represents a single brittlestar. Mean \pm standard deviation is given above each experiment. Data are arranged in ascending order within each experiment

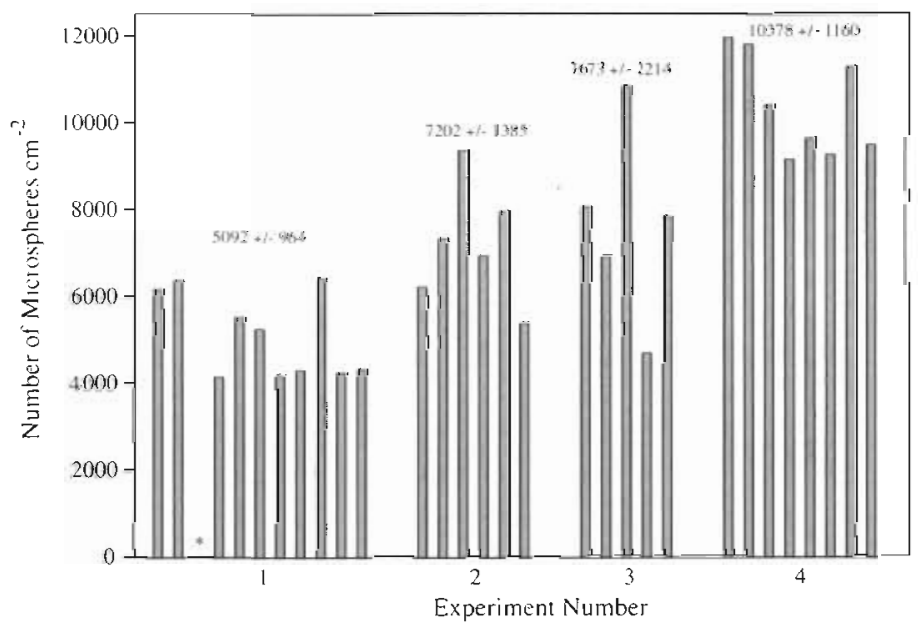

Fig. 2. Estimated initial density of microspheres in experimental containers in subsurface feeding experiments. Each bar represents a single container. Mean \pm standard deviation is given above each experiment. Data are arranged in the same order as Fig. 1 *No data were available

Table 1. Analysis of deviance results for initial microsphere densities in experimental containers within the 4 subsurface feeding experiments, stratified by experiment. 'Significant results at alpha $=0.10$

\begin{tabular}{|clcccc|}
\hline \multirow{2}{*}{ Expt } & Source & $\mathrm{df}$ & Deviance & Chi-square & $\mathrm{p}$ \\
\hline \multirow{2}{*}{1} & Intercept & - & 1.824 & - & - \\
& Container & 10 & 0.982 & 18.732 & $0.044 \cdot$ \\
2 & Intercept & - & 1.311 & - & - \\
& Container & 5 & 0.758 & 9.397 & $0.094 \cdot$ \\
\multirow{2}{*}{3} & Intercept & - & 1.903 & - & - \\
& Container & 5 & 0.815 & 15.438 & $0.009 \cdot$ \\
4 & Intercept & - & 0.389 & - & - \\
& Container & 7 & 0.223 & 10.598 & 0.157 \\
\hline
\end{tabular}

\section{Disc depth experiments}

The results of the ANOVA indicated that experiment had no significant effect on the location of the brittlestars for either of the outcome variables; therefore the 3 disc depth experiments were pooled for further analysis. However, a significant interaction was found between depth and treatment, so comparisons between food and control treatments were conducted at each depth level, and comparisons among the depth levels were performed within each treatment group. Stratifying by depth, we found that when the layers 
Table 2. Dates, mean (standard deviation) water temperature, salinity, and dissolved oxygen measurements for the subsurface feeding experiments

\begin{tabular}{lcccc|}
\hline & Expt 1 & Expt 2 & Expt 3 & Expt 4 \\
\hline Dates (1997) & May 27-28 & May 29-30 & June 4-5 & June 7-8, \\
Temperature $\left({ }^{\circ} \mathrm{C}\right)$ & $23.01(0.457)$ & $21.57(0.552)$ & $21.10(0.074)$ & $19.19(0.113)$ \\
Salinity (ppt) & $31.9(0.421)$ & $33.0(0.122)$ & $32.5(0.345)$ & $28.9(0.973)$ \\
Dissolved & $6.00(0.148)$ & $5.51(0.318)$ & $5.00(0.398)$ & $6.66(0.354)$ \\
oxygen (mg l $\left.{ }^{-1}\right)$ & & & & \\
\hline
\end{tabular}

were $3.5 \mathrm{~cm}$ deep brittlestars in the food treatment were located significantly closer to the treatment layer $(\mathrm{p}=0.019)$ than brittlestars in the control treatment. There were no significant differences, however, between food and control treatments at $6.5 \mathrm{~cm}(\mathrm{p}=$ $0.963)$, or at $9.5 \mathrm{~cm}(\mathrm{p}=0.088)$. At $3.5 \mathrm{~cm}$ all brittlestars were at or below the treatment layer (Fig. 3). In the $6.5 \mathrm{~cm}$ food treatment all brittlestars were found at or above the layer; the brittlestars in the control were found at, above, and below the layer. At $9.5 \mathrm{~cm}$ all brittlestars were found at or above the treatment layer (Fig. 3). Residual analysis identified no strong departures from the model assumptions. In particular, the

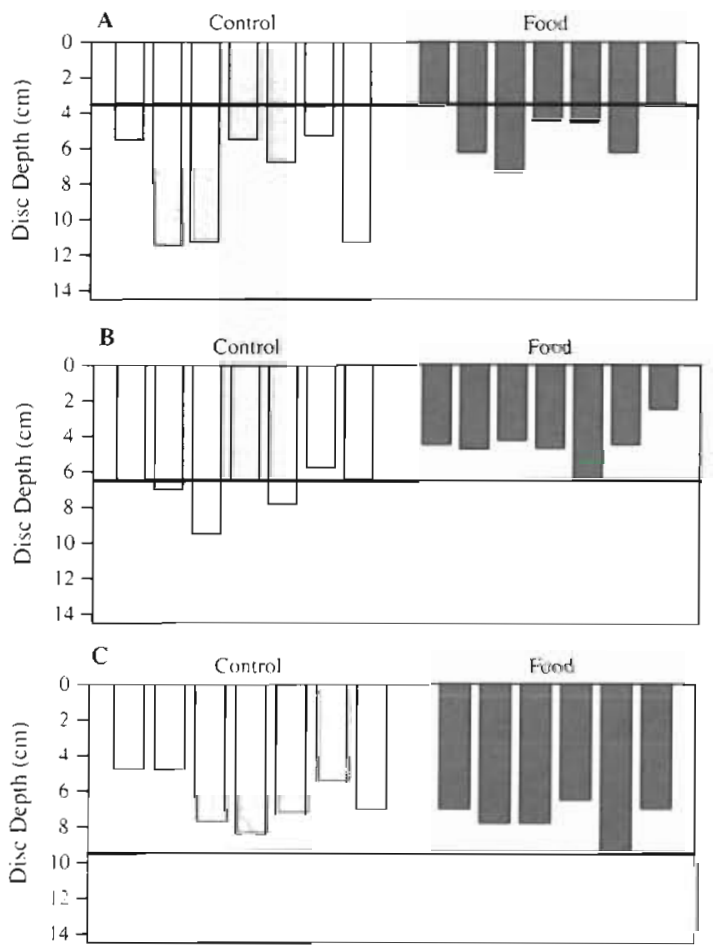

Fig. 3. Amphipholis gracillima. Measured disc depth of brittlestars from the sediment surface. Each bar represents an individual (dark bars $=$ food treatment, light bars $=$ control treatment). The horizontal bold lines indicate the location of the treatment layer. (A) treatment layer $3.5 \mathrm{~cm}$ deep, (B) treatment layer $6.5 \mathrm{~cm}$ deep, and $(C)$ treatment layer $9.5 \mathrm{~cm}$ deep
Shapiro-Wilk test showed no significant departure from normality.

When comparisons between depths within treatments were performed, the depth of the control layers had no significant effect on the disc depth of the brittlestars $(\mathrm{p}=0.434)$. However, the depth of the food treatment layer did have a very significant effect on the location of the brittlestars' discs $(\mathrm{p}<0.001)$.

\section{DISCUSSION}

\section{Subsurface feeding experiments}

Amphipholis gracillima consumes subsurface particles in the laboratory, and therefore is capable of both surface and subsurface feeding. Although this has not been conclusively demonstrated before, it is not entirely surprising because many deposit-feeders utilize more than one feeding site (Buchanan 1964, Fontaine 1965, Pentreath 1970, Warner 1982, Lopez \& Levinton 1987). The ability to switch feeding sites might allow an organism to utilize the best food source at any given time or to satisfy a particular portion of its nutritional requirements (Lopez \& Levinton 1987). Fontaine (1965) suggested that utilizing multiple feeding sites could be one of the factors contributing to the success of ophiuroids. In addition, Grassle et al. (1985) suggested that the subsurface deposit-feeding behavior of some benthic invertebrates might lead to more stable populations over time. Feeding on subsurface organic matter might decrease the risk of predation for

Table 3. Analysis of deviance results for the subsurface feeding experiments. Initial microsphere density, water temperature, sex of the brittlestar, dissolved oxygen, and salinity were included as factors possibly influencing the number of microspheres ingested by Amphipholis gracillima. 'Significant factors at alpha $=0.05$

\begin{tabular}{lcccc|}
\hline Source & df & $\begin{array}{c}\text { Scaled } \\
\text { deviance }\end{array}$ & Difference & $p$ \\
\hline Intercept & - & 44.379 & - & - \\
Initial micro- & 1 & 44.379 & $1.37 \times 10^{-4}$ & 0.997 \\
sphere density & & & & \\
Temperature & 1 & 35.606 & 8.773 & $0.003 \cdot$ \\
Sex & 1 & 32.197 & 3.409 & 0.065 \\
Dissolved oxygen & 1 & 28.865 & 3.332 & 0.068 \\
Salinity & 1 & 25.548 & 3.316 & 0.069 \\
& & & & \\
aThe difference in scaled deviance is used as the chi- \\
square test statistic
\end{tabular}


burrowing organisms. Brittlestars feeding on the sediment surface expose arms to passing predators and are frequently subjected to sublethal predation by a variety of organisms (Bowmer \& Keegan 1983, Stancyk et al. 1994). Lost tissue has to be regenerated at a net energetic loss (Singletary 1980, Stancyk et al. 1994). Lindsay \& Woodin (1995) found that losing tissue as a result of sublethal predation caused spionid polychaetes to switch from surface palp feeding to mouth feeding, and possibly to subsurface feeding.

On a global scale, the sediments marine organisms inhabit represent a large and active reservoir of organic carbon (Romankevich 1984, Hedges 1992). Most organic matter reaching the sediment-water interface is respired, some is converted to biomass, some becomes stored in the sediment mixed layer, and very little is preserved in the sedimentary record (Emerson \& Hedges 1988, Gooday \& Turley 1990, Hedges 1992, and references therein). The amount and distribution of subsurface organic matter varies temporally and spatially. Generally, the amount of organic carbon attenuates with depth in the sediment (Berner \& Westrich 1985, Mayer 1994, Santos et al. 1994), but this is not always the case. Organic carbon can increase with depth (Mayer 1994), remain practically constant (Flach \& Heip 1996, Relexans et al. 1996), or vary with no clear pattern (Mayer 1994, Flach \& Heip 1996). Labile subsurface carbon might exhibit less temporal variability than carbon at the sediment surface. Rudnick \& Oviatt (1986) and Flach \& Heip (1996) have found seasonal variability in the amount of organic carbon in surface sediments. Gooday \& Turley (1990) found that seasonal pulses of organic material affect the population dynamics of epibenthic organisms.

Not all of the organic matter found in sediment is available for use by organisms because of its refractory nature (Lopez \& Levinton 1987, Jumars et al. 1990). Mayer (1994) also demonstrated that some organic carbon is located in sediment pores that are 'too small to allow functioning of the hydrolytic enzymes needed for organic decay'. Nevertheless, a portion of the organic matter can be and is utilized by numerous marine surface and subsurface deposit-feeders throughout the world.

Subsurface and surface environments can be radically different as potential feeding sites. In muds and muddy-sands the sediment below the first few centimeters is devoid of oxygen and rich in potentially harmful natural compounds such as sulfides and ammonia (Rhoads 1974). Subsurface microbial communities are different from surface assemblages, and these are both different from the assemblages found in burrow linings (Steward et al. 1996). Burrowing organisms like Amphipholis gracillima keep their burrows filled with oxygen-rich water so that sediment in the burrow walls is enriched with oxygen (Woodley 1975). This oxygenated zone alters the chemical (Aller 1982) and microbial composition (Meyer-Reil 1994) of the sediment. Microbial activity can in turn alter the oxygen and chemical gradients in sediment (Decho 1990).

Many studies, which have claimed to have proof of subsurface deposit-feeding, have relied on less than compelling evidence. Cadée (1979) argued that the capitellid polychaete Heteromastus filiformis fed on subsurface anoxic sediment based solely on the black color of its fecal pellets. Mangum (1964) stated that the maldanid polychaete Clymenella torquata consumed subsurface particles based on her observations that it was burrowed head-down, but Dobbs \& Whitlach (1982) later found this same organism collecting and consuming surface particles.

Subsurface deposit-feeding has been mentioned in studies of echinoderms, especially holothurians (e.g. Fish 1967, Roberts 1979, Fankboner 1981), but again most of the evidence is anecdotal. Among ophiuroids, Woodley (1975) suggested that several burrowing amphiurid brittlestars probably feed below the surface on deposited material. Pentreath (1970) surmised that Monamphiura aster fed on subsurface sand and 'detrital material' because the sediment surrounding its burrow showed 'no evidence of being swept by the arm'. Singletary (1970) conducted an experiment specifically designed to demonstrate subsurface feeding behavior in several amphiurid brittlestars, including Amphipholis gracillima. Unfortunately, this study made no mention of carmine particles being seen at the surface during or after the allotted feeding time. Singletary noted that carmine particles he found in the brittlestars' stomachs might have been ingested from the sediment surface (Singletary 1970, p. 66). This argument is not trivial; in our experiments microspheres were brought to the surface by the burrowing activity of $A$. gracillima within $10 \mathrm{~min}$ of being placed in the experimental container. The burrowing activity of the brittlestars resulted in microspheres being continuously brought to the sediment surface, and experiments required constant observation and removal of microspheres to prevent ingestion from the sediment surface.

Of the factors we considered a priori, water temperature was the only one to have a statistically significant effect on the number of subsurface microspheres found in guts. Temperature is known to influence activity levels and feeding behaviors of many benthic marine invertebrates including ophiuroids (e.g. Rhoads 1974, Powell 1977, Feder 1981, Kudenov 1982, Stancyk et al. 1994). However, the difference in temperature seen in our experiments was relatively small for an environment where temperatures can fluctuate more than $15^{\circ} \mathrm{C}$ over one tidal cycle, so this effect may not be biologically meaningful. 
Particle selection by deposit-feeding organisms has been addressed frequently (e.g. Powell 1977, Jumars et al. 1982, Taghon 1982, Self \& Jumars 1988). Many organisms preferentially ingest small particles of low specific gravity and large surface areas (Taghon 1982 , Self \& Jumars 1988). Clements \& Stancyk (1984) found that Amphipholis gracillima selected smaller proteincoated particles over larger ones. Our experiments raise questions about the ability of these brittlestars to actively select particles. A. gracillima ingested the small uncoated microspheres, which had no nutritional value, with sediment particles of a wide range of sizes and shapes. However, they may have selected microspheres based on chemical charge, specific gravity, or surface texture, all of which have been shown to influence particle selection in invertebrates (Jumars et al. 1982, Taghon 1982, Self \& Jumars 1988).

When the numbers of microspheres ingested were converted to a rate, the results varied widely, ranging from 0 to 97 microspheres $\mathrm{h}^{-1}$. This wide range is due in some part to differences between individual brittlestars, differences between the number of microspheres in each layer, and variability in the proportion of the microsphere layer individual brittlestars contacted. A. gracillima burrows approximately $9 \mathrm{~cm}$ into the sediment and extends 1 to 3 arms to the sediment surface. If brittlestars were burrowed below the layer, contact with the layer could have been as small as the area around arms extending to the surface. Arms in the center of the container would not contact the layer because of the core of sediment removed when the brittlestars were inserted. Brittlestars with discs at the layer or arms extending into the layer could contact many more microspheres. Because we do not know the gut retention time for $A$. gracillima, gut filling may have occurred more than once during the $12 \mathrm{~h}$ experiment. For these reasons our estimates are at best a conservative measure of feeding rate.

The highly variable initial densities of microspheres added to the containers were taken into consideration in the statistical analyses. We believe the primary factor causing different densities of microspheres was variation in microsphere diameter, which had a $10 \%$ coefficient of variation (Bulletin 93F, June 1, 1994, Duke Scientific Corporation). Errors in weighing the microspheres could result in different numbers of microspheres. Numerical estimates based on weight are unfortunately an inaccurate substitute for counting.

\section{Disc depth experiments}

In the field, Singletary (1980) found Amphipholis gracillima burrowed in sediment to an average depth of $10 \mathrm{~cm}$ \& Stancyk et al. (1994) found them at 8 to $10 \mathrm{~cm}$ in their field cores. In these laboratory experiments, A. gracillima usually burrowed more shallowly (average of $6.5 \mathrm{~cm}$ deep), possibly as an artifact of the $14.5 \mathrm{~cm}$ tall containers in which brittlestars were held. Brittlestars in the food treatments where the layer was 3.5 or $6.5 \mathrm{~cm}$ deep were found shallower than those brittlestars in food treatments where the layer was $9.5 \mathrm{~cm}$ deep (Fig. 3). The significant difference between treatments when the layers were $3.5 \mathrm{~cm}$ deep was particularly meaningful when coupled with the results of the comparisons between depths within treatments, where the depth of the food layers had a significant effect on the depth of brittlestars. We believe that the brittlestars were responding to the Tetramin $^{\otimes}$ in the food layers. If brittlestars had been responding to the physical characteristics of the layer, such as sediment density, grain size, or unmeasured chemical or microbial characteristics, we would have expected to see an effect of the depth of the layer on the burrowing depth of brittlestars in controls. More experiments with larger sample sizes that include treatments to test for other factors could clarify the extent to which subsurface food concentration influences the location of the brittlestars' discs.

Amphipholis gracillima usually extencts 3 arms to the sediment surface, the two that are kept below the surface could forage for subsurface nutrients. Surface and subsurface patches of organic matter are likely to vary spatially and temporally in the marine environment (Mayer 1994, Flach \& Heip 1996); when a patch is created by the death of an organism, for example, bacterial degradation will begin quickly. If an infaunal organism such as a brittlestar locates a subsurface patch of organic matter with an arm, moving closer would expedite consumption. Food patches are likely to be degraded rapidly so it would be best for the organism to take full advantage of it as quickly as possible.

\section{CONCLUSIONS}

Amphipholis gracillima ingests subsurface as well as surface particles. Because deposit-feeders such as $A$. gracillima ingest sediments of low nutritional value, the ability to utilize all food resources available in their habitat seems logical. Infaunal brittlestars probably actively burrow close to patches of organic matter. The methods we have devised could be used to determine whether other infaunal deposit-feeders consume subsurface particles. If other infaunal ophiuroids utilize subsurface organic matter, turnover rates in the subsurface environments they occupy may be higher than previously considered. 
Acknowledgements. We would like to thank R. J. Feller and 3 anonymous reviewers for suggestions that improved this manuscript. S. L. Hedge and P. Studer provided field assistance. This work was greatly enhanced by assistance from I H. Shepherd and D. L. Hoskins. The Marine Science Program and the School of the Environment of the University of South Carolina supported this research. This is contribution no. 1169 of the Belle W. Baruch Institute for Marine Biology and Coastal Research.

\section{LITERATURE CITED}

Aller RC (1982) The effects of macrobenthos on chemical properties of marine sediment and overlying water. ln: McCall PL, Tevesz MJS (eds) Animal-sediment relations: the biogenic alteration of sediments. Plenum Press, New York, p 53-102

Barnard JL, Ziesenhenne FC (1961) Ophiuroid communities of southern California coastal bottoms. Pacif Nat 2 $131-152$

Berner RA, Westrich JT (1985) Bioturbation and the early diagenesis of carbon and sulfur. Am J Sci 285:193-206

Blegvad $H$ (1914) Food and conditions of nourishment among the communities of invertebrate animals found on or in the sea bottom in Danish waters. Rep Dan Biol Stn 22:41-78

Bowmer T, Keegan BF (1983) Field survey of the occurrence and significance of regeneration in Amphiura filiformis (Echinodermata: Ophiuroidea) from Galway Bay, west coast of Ireland. Mar Biol 74:65-71

Brandes JA, Devol AH (1995) Simultaneous nitrate and oxygen respiration in coastal sediments: evidence for discrete diagenesis. J Mar Res 53(5):771-797

Buchanan JB (1964) A comparative study of some features of the biology of Amphiura filiformis and Amphiura chiajei (Ophiuroidea) considered in relation to their distribution. J Mar Biol Assoc UK 44:565-576

Cadée GC (1979) Sediment reworking by the polychaete Heteromastus filiformis on a tidal flat in the Dutch Wadden Sea. Neth J Sea Res 13:441-456

Clements LAJ, Stancyk SE (1984) Particle selection by the burrowing brittlestar Micropholis gracillima (Stimpson) (Echinodermata: Ophiuroidea). J Exp Mar Biol Ecol 84: $1-13$

Decho AW, Moriarty DJ (1990) Bacterial exopolymer utilization by a harpacticoid copepod: a new methodology and results. Limnol Oceanogr 35(5):1039-1049

Dobbs FC, Whitlatch RB (1982) Aspects of deposit-feeding by the polychaete Clymenella torquata. Ophelia 21(2): $159-166$

Duineveld GCA, Van Noort GJ (1986) Observations on the population dynamics of Amphiura filiformis (Ophiuroidea: Echinodermata) in the southern North Sea and its exploitation by the dab, Limanda limanda. Neth J Sea Res 20:85-94

Emerson S, Hedges JI (1988) Processes controlling the organic carbon content of open ocean sediments. Paleoceanography 3(5):621-634

Fankboner PV (1981) A re-examination of mucus feeding by the sea cucumber Leptopentacta (= Cucumaria) elongata. J Mar Biol Assoc UK 61:679-683

Fauchald K, Jumars PA. (1979) The diet of worms: a study of polychaete feeding guilds. Oceanogr Mar Biol Annu Rev 17:193-284

Feder HM (1981) Aspects of the feeding biology of the brittle star Ophiura texturata. Ophelia 20(2):215-235

Feder HM, Pearson TH (1988) The benthic ecology of Loch Linnhe and Loch Eil, a sea-loch system on the west coast of Scotland. V Biology of the dominant soft-bottom epifauna and their interaction with the infauna. J Exp Mar Biol Ecol 116:99-134

Fish JD (1967) The biology of Cucumaria elongata (Echinodermata: Holothuroidea). J Mar Biol Assoc UK 47:129-143

Flach E, Heip C (1996) Vertical distribution of macrozoobenthos within the sediments on the continental slope of the Goban Spur Area (NE Atlantic). Mar Ecol Prog Ser 141. $55-66$

Fontaine AR (1965) The feeding mechanisms of the ophiuroid Ophiocomina nigra. J Mar Biol Assoc UK 45:373-385

Gooday AJ, Turley CM (1990) Responses by benthic organisms to inputs of organic material to the ocean floor: a review. Phil Trans R Soc Lond A 331:119-138

Grassle JF, Grassle JP, Brown-Leger LS, Petrecca RF, Copley NJ (1985) Subtidal macrobenthos of Narragansett Bay. Field and mesocosm studies of the effects of eutrophication and organic input on benthic populations. In: Gray JS, Christiansen ME (eds) Marine biology of polar regions and effects of stress on marine organisms. John Wiley and Sons, New York, p 421-434

Grossmann S, Reichardt W (1991) Impact of Arenicola marina on bacteria in intertidal sediments. Mar Ecol Prog Ser 77 : $85-93$

Hedges JI (1992) Global biogeochemical cycles: progress and problems. Mar Chem 39:67-93

Hendler G, Miller JE, Pawson DL, Keir PM (1995) Sea stars, sea urchins, and allies: echinoderms of Florida and the Caribbean. Smithsonian Institute Press, Washington DC

Hunt OD (1925) The food of the bottom fauna of the Plymouth fishing grounds. I Mar Biol Assoc UK 13:560-599

Hyman LH (1955) The invertebrates, Vol 4. Echinodermata: the coelomate bilateria. McGraw-Hill, New York

Jumars PA, Self RFL, Nowell ARM (1982) Mechanisms of particle selection by tentaculate deposit-feeders. J Exp Mar Biol Ecol 64:47-70

Jumars PA, Mayer LM, Deming JW, Baross JA, Wheatcroft RA (1990) Deep-sea deposit-feeding strategies suggested by environmental and feeding constraints. Phil Trans $R$ Soc Lond A 331:85-101

Kudenov JD (1982) Rates of seasonal sediment reworking in Axiothella rubrocincta (Polychaeta: Maldanidae). Mar Biol 70:181-186

Levinton JS (1989) Deposit feeding and coastal oceanography. In: Lopez G, Taghon G, Levinton J (eds) Ecology of marine deposit feeders. Springer-Verlag, New York, p 1-23

Lindsay SM, Woodin SA (1995) Tissue loss induces switching of feeding mode in spionid polychaetes. Mar Ecol Prog Ser 125: $159-169$

Lopez GR, Levinton JS (1987) Ecology of deposit-feeding animals in marine sediments. Q Rev Biol 62(3):235-260

Mangum CP (1964) Activity patterns in metabolism and ecology of polychaetes. Comp Biochem Physiol 11:239-256

Mayer LM (1994) Surface area control of organic carbon accumulation in continental shelf sediments. Geochim Cosmochim Acta 58(4):1271-1284

Meyer-Reil LA (1994) Microbial life in sedimentary biofilms the challenge to microbial ecologists. Mar Ecol Prog Ser 112:303-311

Moore DS, McCabe GP (1993) Introduction to the practice of statistics, 2nd edn. WH Freeman and Company, New York

Neter J, Wasserman W, Kutner MH (1990) Applied linear statistical models: regression, analysis of variance, and experimental design, 3rd edn. Richard D Irwin Inc, Boston

Olsen CR, Cutshall NH, Larsen IL (1982) Pollutant-particle associations and dynamics in coastal marine environments: a review. Mar Chem 11:501-533 
Pape-Lindstrom PA, Feller RJ, Stancyk SE, Woodin SA (1997) Sublethal predation: field measurements of arm tissue loss from the brittlestar, Microphiopholis gracillima (Stimpson) and immunochemical identification of its predators in North Inlet, South Carolina. Mar Ecol Prog Ser 156: 131-140

Pentreath RJ (1970) Feeding mechanisms and the functional morphology of podia and spines in some New Zealand ophiuroids (Echinodermata). J Zool 161:395-429

Piegorsch WW, Bailer AJ (1997) Statistics for environmental biology and toxicology. Chapman \& Hall, London

Powell EN (1977) Particle size selection and sediment reworking in a funnel feeder, Leptosynapta tenuis (Holothuroidea, Synaptidae). Int Rev Ges Hydrobiol 62(3):385-408

Relexans JC, Deming J, Dinet $A_{1}$ Gaillards JF, Sibuet $M$ (1996) Sedimentary organic matter and micro-meiobenthos with relation to trophic conditions in the tropical northeast Atlantic. Deep-Sea Res I 43(8):1343-1368

Rhoads DC (1974) Organism-sediment relations on the muddy sea floor. Oceanogr Mar Biol Annu Rev 12: $263-300$

Roberts D (1979) Deposit-feeding mechanisms and resource partitioning in tropical holothurians. J Exp Mar Biol Ecol $37: 43-56$

Romankevich EA (1984) Geochemistry of organic matter in the ocean. Springer-Verlag, New York

Rudnick DT, Oviatt CA (1986) Seasonal lags between organic carbon deposition and mineralization in marine sediments. J Mar Res 44:815-837

Ruppert E, Fox R (1988) Seashore animals of the southeast. A guide to common shallow-water invertebrates of the southeast Atlantic coast, 1st edn. University of South Carolina Press, Columbia, p 70-73

Santos V, Billett DSM, Rice AL, Wolff GA (1994) Organic matter in deep-sea sediments from the Porcupine Abyssal Plain in the north-east Atlantic Ocean. Deep-Sea Res I $41(5 / 6): 787-819$

SAS Institute Inc (1989) SAS/STAT ${ }^{\otimes}$ user's guide, Version 6 , 4th edn, Vol 2. SAS Institute Inc, Cary, NC

SAS Institute Inc (1990) SAS procedures guide, Version 6 , 3rd edn. SAS Institute Inc, Cary, NC

SAS Institute Inc (1993) SAS ${ }^{\oplus}$ Technical Report P-243, SAS/STAT ${ }^{\infty}$ software: the GENMOD procedure, Release 6.09. SAS Institute Inc, Cary, NC

Self RFL, Jumars PA (1988) Cross-phyletic patterns of particle selection by deposit feeders. J Mar Res 46:119-143

Editorial responsibility: Kenneth Tenore (Contributing Editor), Solomons, Maryland, LS,
Shapiro SS, Wilk MB (1965) An analysis of variance test for normality (complete samples). Biometrika 52:591-611

Singletary R (1970) The biology and ecology of Amphioplus coniortodes, Ophionepthys limicola, and Micropholis gracillima (Ophiuroidea: Amphiuridae). PhD dissertation, University of Miami, FL

Singletary R (1980) The biology and ecology of Amphioplus coniortodes, Ophionepthys limicola, and Micropholis gracillima (Ophiuroidea: Amphiuridae). Caribb J Sci $16(1-4): 39-55$

Skjaeveland SH (1973) Ecology of echinoderms in Borenfjorden, North-Trondelag, Norway. University of Trondheim, the Royal Norwegian Society of Sciences and Letters, Trondheim

Stancyk SE, Golde HM, Pape-Lindstrom PA, Dobson WE (1994) Born to lose. I. Measures of tissue loss and regeneration by the brittlestar Microphiopholis gracillima (Echinodermata: Ophiuroidea). Mar Biol 118:451-462

Steward CC, Nold SC, Ringelberg DB, White DC, Lovell CR (1996) Microbial biomass and community structures in the burrows of bromophenol producing and non-producing marine worms and surrounding sediments. Mar Ecol Prog Ser 133:149-165

Taghon GL (1982) Optimal foraging by deposit-feeding invertebrates: roles of particle size and organic coating. Oecologia 52:295-304

Theiling D (1988) Assessment of participation and resource impact of shrimp baiting in coastal South Carolina during 1987. South Carolina Marine Resources Center, Technical Report No. 69, South Carolina Wildlife and Marine Resources Department, Charleston

Thomas LP (1962) The shallow water amphiurid brittle stars (Echinodermata, Ophiuroidea) of Florida. Bull Mar Sci Gulf Caribb 12(4):623-694

Thorson G (1957) Bottom communities. In: Hedgepeth J (ed) Treatise on marine ecology and paleoecology, Vol 1, Ecology. Geological Society of America. New York, p $461-534$

Ward JE, Targett NM (1989) Influence of marine mircoalgal metabolites on the feeding behavior of the blue mussel Mytilus edulis. Mar Biol 101:313-321

Warner G (1982) Food and feeding mechanisms: ophiuroidea. In: Jangoux M. Lawrence JM (eds) Echinoderm nutrition. AA Balkema, Rotterdam, p 161-181

Woodley JD (1975) The behaviour of some amphiurid brittlestars. J Exp Mar Biol Ecol 18:29-46

Submitted: June 30, 1998; Accepted: January 22, 1999

Proofs received from author(s): July 20, 1999 